\title{
DAMPAK PEMIKIRAN AHLI RA'Y \\ TERHADAP HUKUM ISLAM KONTEMPORER
}

\author{
Taufik Abdillah Syukur \\ Universitas Islam Negeri Syarif Hidayatullah Jakarta \\ abdillah2803@gmail.com
}

\section{Abstract}

Some islamic experts, Ulama, say that the Islamic Shariah which is contained in the Qur'an and Hadith can be understood its contents. These islamic thinking methods are called "Ra'y" while those involved are called "ahlial-ray". They also use hadith as the istinbath basis of Islamic law. Only in establishing the law, they say that Nash Syar'I has a specific purpose and cumulatively aims to bring benefit to the human being. The researcher will try to reexamine the things related to Ahlual-Ray, Either thoughts or istinbath methodology, then related with the impact on the thoughts of contemporary Islamic law. This study includes the type of library research which is descriptive analysis through a socio-historical approach.

Keydords: Ra'y Expert, Islamic Law 


\section{Abstrak}

SebagianulamaberpendapatbahwasyariatIslamyangterkandung dalam al-Qur'an dan Hadits itu dapat dipahami isinya. Metode pemikiran hukum Islam seperti ini disebut 'ra'y', sedangkan orang yang berkecimpung dalam hal tersebut dinamakan ahli alra'y. Mereka juga menggunakan hadits sebagai dasar istinbath hukum Islam. Hanya saja dalam menetapkan hukum, mereka berpendapat bahwa nash syar'i itu mempunyai tujuan tertentu dan secara kumulatif bertujuan mendatangkan kemaslahatan bagi ummat manusia. Peneliti akan mencoba meneliti ulang halhal yang terkait dengan ahlu al-ra'y, baik tentang pemikiran, metodologi istinbath, untuk kemudian dihubungkan dampaknya kepada pemikiran hukum Islam kontemporer. Penelitian ini termasuk jenis penelitian kepustakaan (Library Research) yang bersifat diskriptif analisis melalui pendekatan sosio-historis.

Kata kunci : Ahli Ra'y, Hukum Islam 


\section{A. PENDAHULUAN}

$\mathrm{P}$ ada periode Rasulullah Saw. jarang terjadi perbedaan pendapat dalam menetapkan hukum suatu perkara, sebab standar dan rujukan hukum bisa langsung di tanyakan kepada Rasulullah Saw. Tetapi ketika periode sahabat, setelah Rasulullah Saw meninggal dunia, banyak sikap dan fatwa sahabat yang berbeda-beda terutama dalam pemikiran hukum Islam.

Timbulnya beberapa pemikiran dalam hukum Islam itu sebagai akibat dari adanya ijtihad ${ }^{1}$ yang dilegalkan oleh Rasulullah Saw. Salah satu contohnya adalah ketika sahabat hendak berkunjung ke Bani Quraizhah. Kepada mereka, Nabi bersabda;

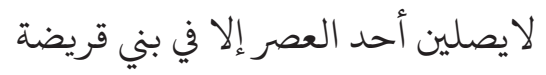

"Janganlah kamu melaksanakan shalat Ashar kecuali di Bani Quraizhah"2

Sebelum sampai ke Bani Quraizhah, waktu Ashar hampir habis. Sebagian sahabat berijtihad dengan melakukan shalat di perjalanan. Berdasarkan ijtihadnya, perintah tersebut adalah supaya sahabat melakukan perjalanan secara cepat sehingga bisa sampai di Bani Quraizhah sebelum waktu shalat Ashar habis. Sebagian sahabat lagi berpegang kepada makna tersurat sabda Nabi Saw tersebut, sehingga mereka shalat Ashar di Bani Quraizhah pada malam hari. ${ }^{3}$

Pemahaman di atas cenderung terbagi menjadi dua; sebagian sahabat memahami hadits secara kontekstual, yaitu yang dimaksudkan oleh nabi agar para sahabat mempercepat perjalanannya menuju Bani Quraizhah, sedang sahabat yang lain memahami hadits secara tekstual dimana mereka harus mematuhi Rasullullah Saw. sesuai dengan bunyi perintah tersebut meskipun waktu shalat Ashar sudah habis.

1 Kata Ijtihad dalam pengertian bahasa berarti mengerahkan kesungguhan untuk mencapai sesuatu atau melakukan suatu pekerjaan. dalam istilah ulama ushul, kata Ijtihad diartikan dengan mengerahkan segala kesungguhan dalam upaya menggali hukum-hukum syara' yang bersifat amali dari dalil-dalilnya secara rinci. selanjutnya, Lihat dalam Muhammad Abu Zahrah, Ushul al-Fiqh, (Mesir: Dar al-Fikr al-Arabi, t.t), h. 379.

2 Hadits riwayat Bukhari no : 894 dan Muslim dari Ibnu Umar no: 3317

3 Shihabuddin Ahmad bin Muhammad al-Qasthalani, Irsyad al-saari fi Syarh Shahih Bukhari, (Beirut: Dar al-Kitab al-Arabi, 1984), Jilid 6, Cet 7, h. 240 
Pada perkembangan selanjutnya perbedaan pendapat antar sahabat semakin nampak setelah wafatnya Rasulullah Saw. Ini dikarenakan Rasulullah Saw. tidak meninggalkan Fiqh yang telah dikodifikasikan, tetapi Rasulullah Saw hanya meninggalkan Ushul al-Syariah yang terhimpun dalam al-Qur'an dan Sunnah. ${ }^{4}$ sebagaimana sabda beliau:

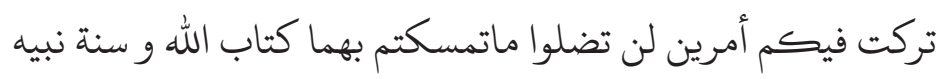

"Telah aku tinggalkan kepada kalian semua dua perkara, jika kalian berpegang teguh kepada keduanya niscaya engkau tidak akan pernah tersesat selamamja yaitu al-Qursan dan Sunnah Nabi". ${ }^{5}$

Ketika kekhalifahan memasuki era kemapanan yang ditopang oleh stabilitas di bidang politik, fiqh sangat diperlukan, Fiqih yang diperlukan itu bukan semata-mata untuk mengatur ibadat, melainkan juga meliputi bidang-bidang kehidupan yang lainnya seperti hubungan antar negara, hukum ketatanegaraan dan administrasi pemerintahan, hukum pidana dan peradilan. Terdorong oleh kebutuhan akan aturan hukum yang sesuai dengan perkembangan masyarakat. ${ }^{6}$

Sebagian ulama berpendapat bahwa syari'at Allah yang terkandung dalam konteks al-Qur'an dan Hadits itu dapat dipahami isinya, karena syari'at itu mempunyai maksud-maksud yang wajib diperhatikan. Metode pemikiran hukum Islam seperti itu dinamakan ra'y, sedangkan orang yang berkecimpung dalam hal itu dinamakan ahlu al-ra'y.

Dalam penelitian ini penulis ingin mencoba kembali meneliti hal-hal yang terkait dengan kelompok ahlu al-ra'y itu, baik yang menyangkut pemikiran, metodologi yang digunakan mereka dalam mengistinbatkan hukum Islam serta menghubungkan pemikiran hukum Islam mereka dengan beberapa pemikiran hukum Islam

4 Ala al-Din Muhammad, Thariqah al-Khilaf baina al-Islaf, (Beirut: Dar al-Kurub al-Alamiyyah, 1992), h. 8

5 Hadits Riwayat Malik dalam Muwatha no : 1365

6 Umar Sulaiman al-Asyqar, Fiqh Islam (Sejarah Pembentukan dan Perkembangannya), Penerjemah : Drs. Dedi Junaedi dan Drs. Ahmad Nurrahman dari buku asli "Tarikh al-Fiqh al-Islamy", cet. 1, 2001, h. v-vi 
kontemporer.

Penelitian ini termasuk dalam jenis penelitian kepustakaan (Library Research), karena data utamanya diperoleh dari buku-buku atau pembahasan yang representatif dan relevan dengan objek studi ini. ${ }^{7}$ Pembahasan ini juga bersifat diskriptif dan analisis. Penulis berusaha menggambarkan objek pembahasan secara lengkap dan jelas, kemudian data-data yang telah terkumpul dianalisis secara mendalam. ${ }^{8}$ Pendekatan sosio-historis dilakukan dengan maksud untuk menguraikan secara detail kontruksi, faktor kondisional dari peristiwa tertentu. ${ }^{9}$

\section{B. PENGERTIAN AHLI RA'Y}

Secara harfiah ra'y berarti pendapat dan pertimbangan. Tetapi orang-orang Arab telah mempergunakan bagi pendapat dan keahlian yang dipertimbangkan dengan baik dalam menangani urusan yang dihadapi. Seseorang yang memiliki persepsi mental dan pertimbangan yang bijaksana dikenal sebagai dzu'l-ra'y. ${ }^{10}$

Ini secara tidak langsung berarti bahwa kesempurnaan intelektual dan kematangan dalam menimbang sesuatu telah lama dijadikan satu kriteria bagi kebesaran seseorang. Qur'an sendiri secara berulang-ulang menyerukan untuk berpikir dalam-dalam dan merenungkan ayat-ayatnya. Ia mengajak untuk menggunakan nalar dan pendapat pribadi dalam persoalan-persoalan hukum. Rasulullah sendiri memberikan contoh dengan menerima pendapat para sahabat dalam persoalan-persoalan di mana beliau tidak dituntun oleh wahyu. Sebagai contoh, pada peristiwa perang Badr, Rasulullah memilih satu tempat tertentu untuk membangun

7 Lihat Abuddin Nata, Metodologi Studi Islam, (Jakarta: FT Raja Grafindo Persada, cet. VI, 2001), h. 125.

8 Analisa data adalah untuk meningkatkan pemahaman penelitian tentang kasus yang diteliti dan menyajikannya sebagai temuan bagi orang lain. Untuk meningkatkan pemahaman tersebut analisis perlu dilanjutkan dengan mencari makna. Lihat Noeng Muhadjir, Metodologi Penelitian Kualitatif, Edisi III, (Yogyakarta: Rake Saraken, Cet. 1,1994), h. 104. h. 11

9 Sartono Kartodirjo, Pendekatan Sosial dalam Metodologi Sejarah, (Jakarta: Gramedia, 1992),

10 Ahmad Hasan, Pintu Ijtihad Sebelum Tertutup, Terjemahan dari The Early Development of Islamic Jurisprudence oleh Agah Garnadi, (Bandung : Penerbit Pustaka, 1984), h. 104-105 
satu perkemahan bagi pasukan Muslimin. Seorang sahabat, Hubaib bin al-Mundzir, bertanya apakah beliau memilih tempat itu atas pertimbangan (ra'y) beliau atau petunjuk Allah. Rasulullah Saw menjawab bahwa pemilihan tempat itu berdasarkan pertimbangan beliau sendiri. Ketika sahabat itu menyarankan suatu tempat yang lebih cocok, Rasulullah menyatakan padanya : Engkau telah memberikan alasan yang masuk akal (laqad asyarta bi'l-ra'y). Rasulullah Saw juga pernah bertukar pikiran dengan para sahabat, suatu ketika beliau menginginkan agar para tawanan Badar dibebaskan dengan tebusan, sedangkan Umar RA mengusulkan agar mereka dibunuh saja. Begitu juga ketika Rasulullah Saw hendak mensalatkan Abdullah Ibn Ubay, kemudian Umar RA mencegahnya karena beliau munafiq. Dalam kasus-kasus tadi, wahyu selalu turun membenarkan Umar. ${ }^{11}$

Istilah ra'y, yang merupakan cara penalaran yang paling ilmiah dimasa awal, lama kelamaan dikenai persyaratan-persyaratan dan pembatasan-pembatasan yang bertujuan untuk menghentikan penggunaan semau-maunya dan mensistematiskan proses penalaran. Bentuk sistematis itu dikenal dengan qiyas.

Meskipun qiyas merupakan bentuk sistematis dari ra'y, tapi terdapat perbedaan besar antara keduanya. Menurut Ibnu Qayyim, ra'y adalah suatu keputusan yang dicapai oleh seseorang setelah melakukan pemikiran, perenungan dan pencarian yang sungguhsungguh akan kebenaran dalam kasus di mana petunjuk-petunjuk yang diperoleh saling bertentangan. Dengan kata lain, ra'y berarti keputusan yang diyakini pasti diambil oleh wahyu seandainya turun, atau oleh Rasulullah, seandainya beliau ada. Sedangkan qiyas adalah perbandingan antara dua hal yang sejajar karena keserupaannya. Keserupaan ini, yang secara tekhnis dikenal sebagai 'illah tidak selamanya dapat ditentukan secara pasti. Orang dapat berbeda paham dalam menentukannya. Begitu juga, bahwa cakupan qiyas jauh lebih terbatas daripada ra'y. Dalam ra'y penekanannya adalah situasi yang aktual, sedangkan pada qiyas penekanannya pada analogi yang abstrak, apapun juga situasi yang ada.

11 Jalaludin Rakhmat, Dahulukan Akhlak di atas Fikih, (Bandung: Muthahhari Press, 2003), cet III, h. 220. 
Ibnu Muqaffa' memberi contoh tentang sifat terbatasnya qiyas. Misalnya seseorang datang berkonsultasi kepada anda mengenai apakah ia harus berbicara bohong atau jujur. Sudah tentu anda akan menyarankan untuk berbicara jujur. Kemudian dia bertanya pada anda apakah ia harus bicara jujur dalam setiap keadaan, katakanlah ketika seseorang berkeinginan untuk membunuh orang tertentu, haruskah ia berkata jujur dan memberikan petunjuk kepada calon pembunuh tersebut dimana kiranya orang yang mau dibunuhnya itu berada. Disini qiyas meminta bahwa ia harus berbicara jujur tetapi ra'y memberi petunjuk agar melanggar aturan, yaitu berbohong tetapi mengambil langkah-langkah yang kiranya bermanfaat. Contoh ini memperlihatkan bahwa qiyas gagal berfungsi dalam berbagai peristiwa karena lingkupnya yang terbatas. ${ }^{12}$

Ibnu Abbas pernah ditanya tentang gigi geraham. Ia menjawab bahwa sebuah gigi geraham memiliki nilai yang sama dengan gigi yang lain sebagaimana halnya dengan jari-jari, yang ganti ruginya adalah sama, tanpa memandang perbedaan ukurannya. Dalam hal ini tidak disangsikan lagi bahwa Ibnu Abbas menggunakan qiyas tetapi ini dilakukannya sangat langsung, sederhana dan wajar, sehingga kita dapat menyebutnya sebagai ra'y. Penilaian terhadap kasus-kasus di mana para sahabat melakukan ijtihad, membawa kita kepada keyakinan bahwa penalaran mereka lebih banyak dicirikan oleh ra'y daripada qiyas yang formal. ${ }^{13}$

Abu Hanifah berpendapat bahwa jika seorang ibu memeluk Islam di daerah musuh dan kemudian pindah ke daerah Islam, maka apabila ia tidak sedang hamil, ia dapat menikah dengan siapapun yang dikehendakinya tanpa ada 'iddah yang mengikatnya. Menurut Abu Yusuf, Abu Hanifah pernah mengemukakan sebuah pendapat tetapi al-Awza'i berbeda pendapat dengannya dalam persoalan itu dan menyatakan bahwa jika seorang perempuan meninggalkan negerinya karena Allah untuk melindungi agamanya, maka kasusnya sama dengan kasus perempuan yang berhijrah dari Makkah ke Madinah pada masa Rasulullah. Ia tak dapat menikah,

12 Ahmad Hasan, Op. Cit., h. 126-127

13 Wael B. Hallaq, Sejarah Teori Hukum Islam(Pengantar untuk Usul Fiqh Mazhab Sunni), (Jakarta: PT Raja Grafindo Persada, 2000), cet I, h. 47 
tambahnya, sampai masa iddahnya habis. Diperincinya pendapat tersebut dengan mengungkapkan bahwa perempuan-perempuan yang pindah dari Makkah ke Madinah itu telah pergi kepada Rasulullah di Madinah sedangkan suami-suami mereka yang masih kafir tinggal di Makkah. Rasulullah mengembalikan isteriisteri tersebut pada suaminya masing-masing ketika suami mereka masuk Islam dan kepada mereka diberikan masa 'iddah. ${ }^{14}$

Orang-orang Madinah juga mempergunakan qiyas dalam memutuskan kasus-kasus hukum, tetapi qiyas mereka juga tidaklah sangat formal dan kaku. kata-kata seperti matsal, ka (seperti), dan bimanzilah sangat umum digunakan untuk menyatakan keserupaan antara dua persoalan yang sejajar. Bahkan satu keserupaan kecil saja sudah cukup bagi mereka untuk menerapkan qiyas dan memutuskan hukumnya.

Ketika membicarakan pemotongan tangan pencuri, Malik mengatakan bahwa jika seorang buruh atau seorang pegawai bekerja pada seseorang kemudian mencuri barang milik majikannya, maka tangannya tidaklah dipotong. Tambahnya, kasus ini tidaklah sejajar dengan kasus seorang pencuri melainkan dengan seorang penggelap, dan tangan seorang penggelap tidaklah dipotong. Lebih jauh diberikannya dua ilustrasi yang serupa. jika seseorang meminjam sesuatu dan menolak untuk mengembalikannya, tangannya tidaklah dipotong. Menurutnya, kasusnya serupa dengan kasus seorang yang berhutang dan menolak untuk membayar hutangnya, dan tangan orang yang berhutang tersebut tidaklah dipotong. Dalam contoh-contoh ini ia mengamati bahwa jika seorang pencuri mengumpulkan barang-barang di satu tempat dalam rumah yang digerayanginya, tetapi barang-barang itu tidak diangkutnya ke luar dari rumah tersebut, maka berdasarkan praktek yang telah disepakati di Madinah, tangannya tidaklah dipotong. Kasusnya serupa dengan seseorang yang menyimpan anggur dihadapannya siap untuk diminum tetapi ia tidak meminumnya. Tidaklah akan jatuh hukuman hadd pada pelaku kejahatan seperti itu. Begitu pula, jika seseorang laki-laki duduk di hadapan seorang 
perempuan dengan hasrat melakuakan perzinahan, hukuman hadd tidak akan dijatuhkan padanya. ${ }^{15}$

Dari contoh di atas penting dicatat bahwa pemotongan tangan merupakan hukuman yang digariskan Qur'an terhadap pencuri. akan tetapi Malik menghapuskan hukuman ini dalam sejumlah kasus atas dasar qiyas. meskipun ini adalah masalah qiyas, Malik mempergunakan istilah ra'y bukan qiyas. Ini menunjukkan bahwa qiyas dalam penalaran orang-orang Madinah pada dasarnya adalah ra'y.

Qiyas pada orang-orang Iraq nampaknya juga merupakan ra'y yang lebih sistematis. Kesistematisannya tidaklah dapat disangsikan. Tetapi ia tidaklah seformal dan sekaku Imam Syafi'i. Perbedaan qiyas antara orang-orang Madinah dan orang-orang Irak ialah bahwa orang-orang Madinah lebih menekankan pada praktek yang telah diterima secara luas, sedangkan orang-orang Irak lebih menuntut konsistensi logika. Orang-orang Iraq, dengan tujuan untuk menghindari ketidakkonsistenan qiyas, dalam lingkupnya yang terbatas waktu itu, menciptakan metode lain yang lebih dekat pada ra'y yang dikenai dengan istihsan. ${ }^{16}$

\section{PEMIKIRAN HUKUM ISLAM AHLI RA'Y}

Adanya perbedaan pendapat tentang masalah hukum Islam pada periode awal Tabi'in nampak jelas dengan terbaginya mereka dalam kelompok ahli hadits dan kelompok ahli ra'y (rasional). Kelompok ahli hadits ini kebanyakan diantara mereka adalah mujtahid Hijaz dan kelompok ahli ra'y kebanyakan di antara mereka adalah mujtahid Irak. Terpolarisasinya mereka dalam kelompok seperti ini, bukan berarti bahwa mujtahid Irak yang rasional dalam menetapkan hukum-hukum tidak bedasarkan hadits-hadits Nabi Saw. sebagaimana halnya juga tidak berarti bahwa mujtahid Hijaz tidak mempertimbangkan alasan rasio dalam menetapkan hukum-hukum. Kedua kelompok tersebut sepakat bahwa hadits-

15 lbid., h. 130

16 lbid. 
hadits Nabi Saw. merupakan dasar hujjah atau salah satu sumber hukum yang tetap, dan ijtihad dengan ra'y atau qiyas (analogis) juga merupakan dasar hujjah atau bagian dari sumber hukum, ketika menghadapi masalah yang tidak ada ketetapan nashnya.

Pembagian dua kelompok tersebut dan pemberian nama ahli hadits mujtahid Hijaz dan ahli ra'y mujtahid Irak, karena ahli fiqh atau mujtahid Irak lebih mengutamakan analisis terhadap maqasid ditetapkannya hukum itu dan asas-asas yang menjadi dasar penetapan hukum itu. Mereka menyadari bahwa hukum-hukum syari'at dapat dimengerti makna dan maksudnya, yaitu dalam rangka terwujudnya kemaslahatan umat manusia, dan dalam penetapannya didasarkan atas satu prinsip dan bermuara pada satu tujuan, sehingga dengan demikian, hukum-hukum yang ditetapkan itu teratur dan tidak saling bertentangan. Dengan dasar seperti ini, mereka memahami nash-nash, dan memandang kuat ketetapan nash atas ketetapan yang lainnya, dan mereka mengistinbatkan hukum dari satu masalah yang tidak ada ketetapan nashnya walaupun dalam istinbat mereka ini berusaha memalingkan makna lahirnya dan mengambil makna yang lebih kuat. Dari segi ini mereka tidak mempersempit arena lapangan ijtihad, akan tetapi justru menjadikan arena tersebut semakin luas dengan kekuatan analisis rasional.

Adapun para ahli fiqh Hijaz lebih mencurahkan perhatiannya dalam menghafal hadits-hadits dan fatwa-fatwa sahabat. Cara mereka dalam menetapkan hukum ialah dengan memahami hadits-hadits itu sesuai dengan ungkapan tekstualnya tanpa banyak menganalisis mengenai illat-illat hukum dan prinsipprinsipnya. Kalau mereka mendapati apa yang mereka pahami dari nash itu tidak sesuai dengan kehendak akal pikiran atau tidak masuk akal, maka mereka tidak memperdulikan hal ini dan mereka mengatakan itu adalah nash. Dengan cara seperti ini mereka telah mempersempit arena lapangan ijtihad dan mereka tidak memakai analisis rasional kecuali pada waktu darurat saja.

Contoh yang terdapat dalam hadits : 
"Setiap empat puluh ekor tombing zakatnya seekor". ${ }^{17}$

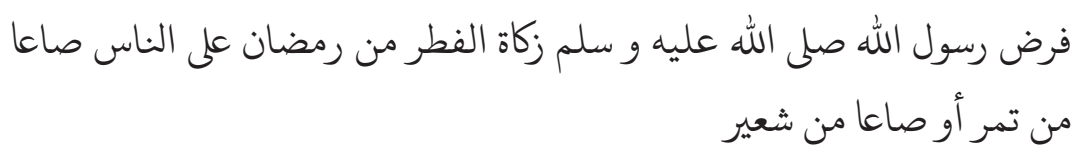

"Rasulullah Saw. telah mewajibkan zakat fitrah pada bulan ramadhan pada manusia berupa satu sha' kurma atau satu sha' gandum". ${ }^{18}$

Para ahli fiqh Irak memahami hadits-hadits tersebut secara rasional, yaitu berdasarkan tujuan ditetapkannya zakat itu. Pemilik empat puluh ekor kambing wajib memberikan seekor kambing rujuannya untuk membahagiakan orang-orang fakir, maka boleh memberikannya seharga dengan kambing itu yang bisa membahagiakan mereka.

Mengeluarkan zakat fitrah tujuannya adalah untuk membuat agar supaya orang-orang fakir menjadi bahagia dan bisa memanfaatkannya yaitu satu sha' buah kurma atau yang lain sama nilainya.

Dengan demikian, disebutkannya kambing atau satu sha' dalam hadits bukanlah itu yang dituntut dan dimaksudkan oleh syara'. Tujuan utamanya dalam keajiban zakat itu adalah untuk memenuhi dan menutupi kebutuhan hidup orang-orang fakir. Maka dengan dasar pertimbangan ini mengeluarkan zakat seekor kambing dengan harganya yang senilai, dan zakat fitrah satu sha' kurma dengan harganya yang senilai adalah boleh dan sah hukumnya. Cara seperti ini juga bisa menutupi kebutuhan mereka.

Adapun ahli fiqh Hijaz memahami hadits-hadits tersebut di atas secara tekstual tanpa mempertimbangkan Maksud dan tujuan ditetapkannya hukum zakat itu sehingga mereka tetap mewajibkan zakat kambing dan satu sha' kurma itu sendiri sesuai bunyi teks di situ. Tidak sah hukumnya mengganti dengan harganya.

Sumber hukum Islam bagi ahli ra'y adalah al-Qur'an, Sunnah.

17 Hadits riwayatTirmidzi no: 564 dan Abu Daud no: 134

18 Hadits riwayat Bukhari no : 1407 dan Muslim no : 1635 dan 1646 
Istilah ahli ra'y digunakan untuk menyebut kelompok pemikir hukum Islam yang memberi porsi akal lebih banyak dibanding pemikir lainnya. Bila kelompok lain dalam menjawab persoalan hukum Islam tampak terikat oleh teks nash (al-Qur'an dan al-Hadits) maka kelompok ahli ra'y tampaknya tidak terikat, sebaliknya, mereka leluasa menggunakan pendapat akal. Sebenarnya ahli ra'y bukanlah berarti kelompok yang meninggalkan hadits. Mereka juga menggunakan hadits sebagai dasar penetapan hukum Islam. Hanya, mereka dalam melihat kasus penetapan hukum berpendapat bahwa nash syar'i itu mempunyai tujuan tertentu, dan nash syar'i secara kumulatif bertujuan mendatangkan mashlahat manusia (mashalih al-ibad). Karena banyaknya persoalan yang mereka hadapi dan "terbatasnya jumlah nash" maka mereka berupaya memikirkan rahasia yang terkandung di balik nash, dikenai dengan istilah ta'lil al-ahkam. Sedangkan kelompok ahli hadits lebih memperhatikan penguasaan hafalan nash dan mengamalkan sesuatu sesuai bunyi nash itu. ${ }^{19}$

Ahli ra'y merasa bahwa keberhasilan ijtihad dengan ra'yu dapat menyelematkan ummat Islam dari persoalan hukum Islam, karenanya metode ini terus dikembangkan. Lebih dari itu mereka kemudian mengandaikan hal-hal yang kemungkinan terjadinya amat jauh. Ini disebabkan karena mereka memperkirakan bahwa wilayah Islam akan bertambah luas terus sehingga persoalan hukum yang mungkin terjadi harus diantisipasi.

Struktur berpikir ahli ra'y ini agaknya diilhami oleh sebuah hadits terkenal, dialog antara Nabi Saw. dengan Mu'adz bin Jabal ketika beliau hendak mengutusnya ke Yaman sebagai qadhi (hakim).

$$
\text { كيف تقضي؟ قال أقضي بكتاب الله قال فإن لم تجد قال أقضي بسنة رسول الله }
$$

"Dengan apa engkau memutuskan perkara nanti ?, Nabi Saw. bertanya. Mu'adz menjawab, dengan Kitab Allah. Kalau dalam Kitab Allah tidak ada ?. Dengan Sunnah Rasul. Kalau dalam Sunnah Rasul juga tidak ada

19 Dr. Muhammad Zuhri, Op. Cit., h. 70 
? Saya berijtihad dengan ra'y saya. ${ }^{20}$

Dialog itu mengandung ajaran bahwa ra'y yang sehat itu dapat dijadikan acuan untuk menyelesaikan persoalan hukum. Dengan kata lain, sumber hukum Islam berdasarkan alur pikir tersebut ada tiga;

1. Al-Qur'an

2. Al-Sunnah

3. Al-Ra'y

Ini agaknya cikal-bakal pemikiran yang dikembangkan dalam teologi muktazilah. Disana diyakini bahwa wahyu (al-Qur'an dan Sunnah) itu mempunyai dua fungsi:

1. Konfirmasi terhadap akal pikiran dan

2. Konfirmasi terhadap capaian akal pikiran.

Dimaksud dengan fungsi informasi adalah pengakuan bahwa kesanggupan akal manusia itu terbatas. Tidak semua nilai baik dan buruk itu dapat dicapai oleh akal. Disini akal membutuhkan informasi. Karenanya, menurut jalan pikiran ini., Tuhan wajib 'aqli menurunkan wahyu. Sedangkan dimaksud dengan fungsi konfirmasi adalah bahwa kebenaran yang dicapai oleh akal dikukuhkan oleh wahyu. Artinya, akal sebenarnya mempunyai kekuatan menemukan kebenaran.Fenomena yang disebut eksplisit oleh wahyu dipercayakan oleh Tuhan kepada akal manusia untuk menyelesaikannya. Maka disini benar bahwa akal adalah sumber hukum yang ketiga, setelah yang pertama al-Qur'an dan yang kedua al-Sunnah.

Sebaliknya ahli hadits lebih cenderung kepada kecilnya fungsi akal. Boleh dikata, akal tidak punya peranan untuk menentukan baik dan buruk tanpa wahyu. Dalil yang digunakan adalah :

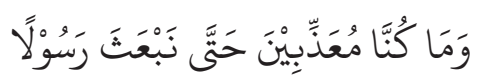

"Dan kami tidak akan menyiksa manusia sebelum mengutus seorang Rasul."

20 Hadits riwayat Tirmidzi no : 1349 dan Ahmad no: 21000, 21049 dan 21084

21 Surat al-Isra'; 17 
Ayat ini mengandung maksud bahwa karena wahyu yang dibawa oleh utusan-Nya belum sampai kepada ummatnya maka perilaku salah (menurut akal) tidak dibalas dengan siksa. Ini mengandung arti bahwa akal tidak mempunyai kekuatan menemukan kebenaran seperti dipahami oleh ahli ra'y. Maka menurut ahli hadits, wahyu hanya mempunyai satu fungsi informasi terhadap akal. ${ }^{22}$

Faktor-faktor paling penting yang menyebabkan terjadinya perbedaan antara ahli fiqh Irak dan ahli fiqh Hijaz dalam menetapkan hukum tersebut, ialah:

Hadits-hadits Nabi Saw. dan fatwa-fatwa para sahabat tidak banyak terdapat di Irak, tetapi kebanyakan ada di Hijaz. Penduduk Hijaz mempunyai perbendaharaan hadits yang mereka jadikan pegangan dan pedoman dalam menetapkan hukum. Sedangkan ahli fiqh Irak tidak mempunyai perbendaharaan hadits seperti ini, sehingga mereka dalam menetapkan hukum itu menggunakan kekuatan akal pikiran, mereka berijtihad dalam memahami tujuan nash dan sebab-sebab ditetapkannya hukum itu.

Irak merupakan tempat berkembangnya usaha-usaha pemalsuan hadits-hadits, karena di sana tempat basis masa Syi'ah dan Khawarij. Para ahli fiqh Irak sudah menyaksikan aksi pemalsuan hadits, sedang ahli fiqh Hijaz tidak menyaksikannya. Oleh karena itulah, para ahli fiqh Irak sangat ketat dan berhati-hati dalam menerima riwayat-riwayat hadits, mereka hanya menerima hadits-hadits yang benar-benar sudah populer di kalangan ahli fiqh saja. Kalau mereka mendapatkan suatu hadits yang muatannya dipandang tidak relevan dengan hikmah atau tujuan penetapan hukum dalam syari'at, maka mereka menta'wil hadits itu atau meninggalkannya.

Situasi kondisi di Irak berbeda dengan di Hijaz. Sistem interaksi sosial, muamalah tradisi dan tata aturan yang ada di Irak merupakan warisan dari kerajaan Persi yang pernah menguasai Irak masa lalu. Lapangan arena ijtihad di Irak lebih luas dan diskursus pelbagai masalah lebih hidup dan semarak. Jadi lebih cenderung menggunakan analisis rasional ketika menetapkan hukum 
suatu persoalan. Sedang ahli fiqh Hijaz hanya menyesuaikan diri sebagaimana apa yang pernah terjadi pada para pendahulu dan guru mereka dari kalangan sahabat dan tabi'in, di mana situasi kondisi sosial masyarakatnya bersifat homogen, satu macam, dan sedikit sekali terjadi pada mereka persoalan, kesalahan baru yang ketetapan hukumnya tidak ada dalam hadist-hadits Nabi Saw. dan fatwa-fatwa sahabat. Sedangkan para ahli fiqh Hijaz tidak menemui dan merasakan arena dan lapangan ijtihad dan diskursus seperti yang ditemui dan dirasakan oleh ulama-ulama Irak.

Oleh karena itulah, para ahli fiqh Hijaz dalam menetapkan hukum, mereka memahami nash-nash al-Qur'an dan hadits itu secara lahirnya, tanpa mengkaji illat-illatnya dan tidak mendalami tujuan-tujuan yang ingin dicapai dalam penetapan hukum itu oleh syariat. ${ }^{23}$

Dari uraian diatas dapat kita simpulkan beberapa persamaan dan perbedaan diantara dua aliran tersebut terutama ketika masa tabi'in, hal-hal tersebut sebagai berikut:

1. Bahwa kedua aliran tersebut menjadikan al-Qur'an dan Hadits sebagai sumber hukum

2. Kedua aliran tersebut mempunyai penilaian yang hampir sama tentang hadits, baik itu di tingkat suyukh (guru) atau pada adad (jumlah).

3. Kedua aliran di catas sama-sama menggunakan ra'y dalam mengistinbatkan hukum Islam dan menggabungkan segala pendapat, fatwa dan qadha para sahabat serta menjadikan semua itu sebagai i'tibar atau penguatan terhadap ketetapan hukum mereka.

4. Ra'y yang mereka gunakan saat itu belumlah terbentuk suatu istilah khas sebagaimana yang terjadi pada masa Imam Syafi'i. Ra'y bisa saja berbentuk qiyas, Istihsan, Mashlahat Mursalah atau Urf dan lain-lain. Ibnu Qayyim menafsirkan ra'y dengan apa-apa yang di lihat oleh hati mereka setelah melalui proses pergumulan pemikiran dan taammul secara terus menerus

23 Wajidi Sayadi, Op. Cit., 93-100 
dalam mencari kebenaran dengan diiringi beberapa argumen dan tanda-tanda.

5. Lingkungan sekitar merupakan faktor penting yang menentukan proses istinbat hukum Islam bagi kedua aliran tersebut. Kota Madinah dengan adat istiadat yang Islami masih tetap terjaga dengan baik. Masih belum terkontaminasi dengan adat istiadat asing. Dengan demikian, tidak terlalu banyak perubahan-perubahan baru yang membutuhkan solusi hukum Islam. Hal ini menjadikan fuqaha Madinah tidak terlalu sulit untuk memberikan fatwa sesuai dengan ruh Islami. Tidak halnya yang terjadi di Irak, lingkungan yang varian terdiri dari berbagai macam corak budaya dan perubahan-perubahan baru yang memerlukan banyak solusi jawaban hukum Islam. Selain itu, di Irak marak sekali perdebatan pemikiran yang memerlukan kemampuan dalam berdiskusi.

6. Setiap aliran membanggakan apa yang mereka peroleh dari para sahabat dan guru-guru mereka. Seperti perkataan Asy Sya'bi (w. 104): tidak ada seorang pun dari sahabat Nabi yang lebih faqih dari pada Abdullah bin Mas'ud. ${ }^{24}$ Abu Majaz berkata : Saya tidak melihat seseorang yang lebih faqih dari pada Asy Sya'bi. ${ }^{25}$

7. Dari dua aliran tersebut ada diantara mereka yang menolak memberikan fatwa jika tidak ditemukan hadits yang berkaitan dengan masalah yang diutarakan. Sebagaimana terdapat pula dari masing-masing aliran yang sering sekali mengeluarkan fatwa dan sering menggunakan akalnya dalam mentakhrij dan mengqiyas. Misalnya di Irak terdapat as-Sya'bi yang enggan mengeluarkan fatwa berbeda dengan Ibrahim An Nakha'i (w. 95 $\mathrm{H})$ yang sering mengeluarkan fatwa. Sebagaimana dikutip dari perkataan ibnu Qutaibah : Ulama ahli Iraq yang enggan untuk menggunakan ra'y dan qiyas adalah as-Sya'bi . Ibnu 'Aun berkata : “Apabila datang suatu permasalahan kepada As Sya'bi maka ia takut menghadapinya sebaliknya dengan Ibrahim, beliau akan

24 Ibnu Saad, Op. Cit., jilid 6, h. 11

25 Ibid., h. 11-12 
menanggapinya." 26 Diriwayatkan dari as-Sya'bi : Sesungguhnya kami bukan ahli fiqh, tetapi kami mendengar hadits maka kami meriwayatkannya. Seorang ahli fiqh adalah orang yang apabila mengetahuinya maka ia mengamalkannya. Ibnu Abi Laila berkomentar : As-Sya'bi adalah orang yang memilik atsar dan Ibrahim adalah pemilik qiyas. Di Hijaz terdapat pula ulamaulama yang sering mengeluarkan fatwa sebagaimana terdapat pula ulama yang sedikit dan berhati-hati dalam mengeluarkan fatwa. Seperti Said bin Musayyab (w. 94 H) sebagai ulama yang sering mengeluarkan fatwa walaupun tidak sedikit ulama yang sezaman dengannya yang mempunyai wawasan keilmuan yang tinggi akan tetapi takut untuk mengeluarkan fatwa. Ibnu Umar pernah berkata bahwa Said bin Musayyab adalah salah satu ahli fatwa. Hasan Basri apabila mengalami kesulitan maka ia akan menulis kepada Sa'id bin Musayyab untuk menanyakannya. Ibnu Hazm memberikan gambaran tentang kondisi ulama saat itu: Rabiah (w. 136 H) banyak sekali menggunakan ra'y dan sedikit mengetahui tentang hadits sedangkan Abu Zunad (w. 131) dan Zaid bin Aslam kedua-duannya sedikit berfatwa. Rabiah adalah seorang hafidz, faqih dan mujtahid, serta memperhatikan ra'y, oleh karena itu ia disebut dengan Rabi'ah $\operatorname{arra}^{\prime} y .{ }^{27}$

8. Kedua aliran terjadi perseteruan yang hebat antara ulama yang sering dan sedikit mengeluarkan fatwa. Konflik itu wajar terjadi pada diri manusia, dan hal demikian bukan hanya sekedar terjadi antara ahli Madinah dan ahli Irak saja. Akan tetapi menyebar sampai ke Mesir. Pada akhirnya kita dapat menyimpulkan bahwa perbedaan pendapat diantara mereka bukan hanya sekedar terjadi karena faktor masingmasing pengakuan mereka terhadap ra'y, akan tetapi banyak faktor yang meruncingkan konflik diantara mereka bahkan sampai ada yang kelewat batas dan terlalu berlebihan ketika berdebat dan saling menjatuhkan antara satu dengan yang

26 Hudhari Bik, Tarikh al-Tasri' al-lslami, diterjemahkan oleh Drs. Mohammad Zuhri, (Indonesia: Daarul Ihya, t.t.), h. 314

27 Hudari Bik, Op. Cit., h. 309 
lainnya. Seperti hubungan antara as-Sya'bi dan Ibrahim anNakhi, sebagaimana yang dilukiskan oleh al-A'mas: ketika itu saya sedang berada di halaqoh as-Sya'bi, murid-muridnya menyebutkan nama Ibrahim an-Nakhi, maka berkata as-Sya'bi bahwa beliau adalah seorang yang berbeda dengan kita.

\section{DAMPAK PEMIKIRAN AHLI RA'Y TERHADAP HUKUM ISLAM KONTEMPORER}

Pada bagian ini, peneliti akan mengangkat beberapa pendapat ulama terkait dengan beberapa masalah kontemporer. Yang menurut hemat penulis pendapat tersebut merupakan dampak daripada pemikiran ahli ra'y di masa lampau. Adapun permasalahan tersebut diantaranya:

\section{a. Kesaksian Wanita}

Dalam lingkup kajian Islam, diantara persoalan yang hampir selalu mengundang kontroversi adalah isu-isu kewanitaan. Sejumlah jawaban dan respon yang telah diberikan selama ini, ternyata tidak cukup menuntaskan masalah yang ada, bahkan dalam banyak kasus justru memicu ketidakpuasan. Dapat dikatakan, bahwa isu kewanitaan merupakan masalah yang kompleks. Tidak sekadar persoalan yang semata-mata bisa didekati dengan pemaparan final doktrin-doktrin keagamaan saja, melainkan harus pula memperhitungkan aspek-aspek sosial budaya, teologi ataupun sensitifitas gender yang belakangan ini terus berkembang.

Allah Swt berfirman:

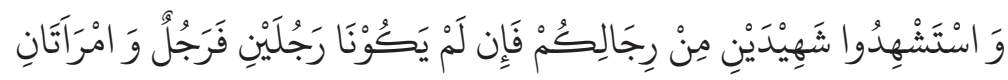

"Dan persaksikan dengan dua orang saksi dari orang lelaki (diantaramu), jika tidak ada dua orang lelaki, maka (boleh) seorang lelaki dan dua orang perempuan"28

Dalam memahami ayat di atas, seringkali justru mengarah 
kepada ketidaksetaraan (inequality) antara laki-laki dan wanita, bahwa wanita itu lebih rendah dari laki-laki, oleh karena itu kesaksian seoarang wanita bernilai separuh dari kesaksian laki-laki. Sehingga para fuqaha' dalam menetapkan masalah kesaksian wanita selalu dengan perbandingan dua orang saksi wanita sama nilainya dengan kesaksian seorang laki-laki. Bahkan lebih jauh lagi yaitu kesaksian wanita tidak dapat diterima dalam masalah pidana ( $q$ işāş dan ḥudūd). Kesaksian wanita baru diakui secara mutlak, tanpa didampingi kesaksian laki-laki hanya terbatas dalam hal yang berkaitan dengan masalah kewanitaan saja, atau hal-hal yang lazim diketahui oleh wanita, seperti masalah haid, cacat pada anggota tubuh wanita, peristiwa kelahiran dan masalah rada'ah..$^{29}$ Dalam suasana dan atmosfir seperti itu, Syaltut menyatakan pendapatnya, bahwa kesaksian seorang wanita itu sama dan setara nilainya dengan kesaksian seorang laki-laki. ${ }^{30}$

Pendapat Syaltut ini tentu saja berbeda dengan pendapat yang selama ini berkembang di kalangan fuqaha, bahwa kesaksian seorang wanita itu setengah dari kesaksian seorang laki-laki, atau dengan formulasi fiqih dinyatakan bahwa kesaksian wanita baru dianggap sah, bila dikemukakan oleh dua orang wanita dan seorang laki-laki.

Dalam menafsirkan surat al-Baqarah (2) ayat 282 Syaltut mengemukakan pendapatnya sebagai berikut: Jika tidak ada dua orang laki-laki, maka (boleh) seorang laki-laki dan dua orang wanita" bukanlah berkenaan dengan saksi di depan hakim (pengadilan) selaku dasar memutuskan perkara, melainkan firman itu berupa petunjuk kearah mendapatkan kepercayaan dan ketentraman hati terhadap hak-hak diantara mereka yang sedang bermuamalah (hutang piutang) saat melaksanakan urusannya. ${ }^{31}$

Dengan demikian, misi dari ayat tersebut menurut

29 Ibn Qayyim al-Jauziyyah, Al-Turuq al-Hukmiyyah fi al-Siasah al-Syar'iyyah, (Kairo : alMu'assasah al-Arabiyyah li al-Tiba'ah wa al-Nasyr, 1961) h. 92-93 \& 151

30 Syaltut, al-lslam Aqidah wa Syari'ah, h. 239-240

31 Ibid., h. 239

90 HIKMAH, Vol. XIV, No. 1, 2018 
Syaltut, penekanannya adalah terletak dalam soal kepercayaan hutang piutang dan bukan di depan pengadilan. Ayat tadi juga memberikan cara dan jalan yang sebaik-baiknya untuk mendapatkan kepercayaan dari pihak yang bersangkutan.

Lebih lanjut Syaltut menyatakan : Ini bukan berarti bahwa persaksian seorang wanita atau beberapa wanita yang tidak beserta laki-laki, tidak dapat menetapkan kebenaran, atau hakim tidak boleh menjatuhkan hukum berdasar itu. Maka sesungguhnya yang paling pokok bagi pengadilan ialah keterangan dan bukti. ${ }^{32}$

Sesungguhnya keterangan dan bukti (al-bayyinah) dalam pandangan syari'ah lebih umum dari saksi, oleh karena itu segala sesuatu yang dapat memberikan keterangan dan memperjelas kebenaran adalah merupakan bukti. Dengan dasar itu pula hakim dapat memutuskan suatu perkara. Berkaitan dengan hal persaksian untuk untuk meraih suatu kebenaran., Ibn Qayyim berpendapat, bahwa saksi itu hanyalah sarana untuk memperoleh kebenaran. Oleh karena itu, jika hakim telah mendapatkan kebenaran, meskipun hanya disampaikan oleh seorang saksi, sudah selayaknyalah ia menerimanya. ${ }^{33}$

Mengapa dalam surat al-Baqarah (2) ayat 282 tersebut dinyatakan dua wanita dan satu laki-laki. Hal tersebut sebenarnya menegaskan bahwa al-Qur'an diwahyukan pada saat kaum wanita tidak lazim berperan serta dalam berbagai transaksi finansial, dan kurang akrab dengan prosedur bisnis dibanding dengan laki-laki, oleh karenanya ingatan wanita itu dalam urusan keuangan lemah (mudah lupa), sebaliknya dalam urusan rumah tangga wanita lebih unggul. Memang sudah menjadi sifat manusia pada umumnya, bahwa ingatannya itu selalu kuat dalam hal yang ia tekuni, berkonsentrasi, dan terlibat di dalamnya. ${ }^{34}$

32 Ibid., h. 240.

33 Syamsudin Abi Abdillah Muhammad bin Abi Bakr al-Jauziyyah, al-Turuq al-Hukmiyyah fi al-Siasah al-Syar'iyyah, (Kairo : al-Muassasah al-Arabiyah Li al-Tiba'ah wa al-Nasyr, 1961), h. 89

34 Syaltut, al-lslam Aqidah wa Syari'ah, h. 240. 
Akan tetapi jika kaum wanita itu berada dalam tradisi ikut terlibat dalam urusan perdagangan, keuangan dan hutang piutang, maka mereka tentu saja berhak mensejajar diri menetapkan kepercayaan kesaksian seoarang wanita, sebagaimana kepercayaan kesaksian seorang laki-laki. ${ }^{35}$ Pandangan masa lalu bahwa wanita dianggap lemah, ini merupakan dampak langsung dari konsep superioritas laki-laki, ini jelas faktor sosiologis semacam itu seringkali berubah menjadi teologis dan dipertahankan sedemikian rupa, sekalipun kondisi sosiologisnya telah berubah. Pada saat sekarang kaum wanita sudah tidak dianggap lagi sebagai kaum yang lemah, dan mereka sudah sepatutnya diperlakukan sama dengan kaum lelaki.

Kondisi sosial wanita pada masa Nabi, sebenarnya merupakan kelanjutan dari masa jahiliyyah. Pada masa jahiliyyah atau sebelumnya Islam datang, wanita tidak mempunyai hak apa-apa bahkan terhadap dirinya sendiri. Kemudian Islam datang dengan membawa perubahan yang progresif dan egaliter. Kaum wanita dilepaskan dari belenggu kezaliman yang memasung mereka di zaman jahiliyyah dan dibebaskan dari kesewenang-wenangan, serta diberikan kepada mereka hak dan kewajiban, sehingga karenanya terangkatlah mereka dari lembah kehinaan. Mereka dijadikan anggota masyarakat yang turut aktif dalam membina ummat dan menjadi tulang punggung dalam membangun masyarakat. Al-Qur'an memang berbicara tentang laki-laki yang memiliki kelebihan dan keunggulan sosial atas diri wanita, untuk itu perlu dilihat dalam konteks sosial yang tepat. Struktur sosial pada masa Nabi saat itu, tidaklah benar-benar mengakui kesetaraan wanita (equality) antara laki-laki dan wanita, hal ini tidak mungkin diambil secara pandang teologis semata, tetapi harus dipandang secara sosioteologis karena al-Qur'an pun terdiri dari ajaran normatif dan kontekstual, karena studi alQur'an tidak bisa efektif jika mengabaikan konteks sama sekali. 
Sebagaimana Firman Allah SWT :

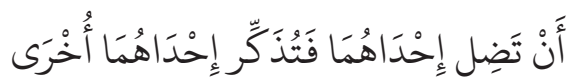

"Supaya jika seorang lupa, maka yang seorang lagi mengingatkannya". ${ }^{36}$

Ayat tersebut memberikan pengertian bahwa kesaksian dua wanita itu diupayakan, supaya jika salah seorang di antara keduanya membuat kesalahan, maka yang lain mengingatkan. Menurut Rasyid Ridha, bahwa pada masa itu seorang wanita memang kurang lazim terlibat dalam urusan keuangan dan perdagangan, sehingga bisa terjadi kemungkinan bagi wanita kurang kuat ingatannya dalam persoalan itu. ${ }^{37}$ Untuk itu satu dengan yang lain perlu saling mengingatkan, agar tidak tergelincir melakukan kesalahan.

Aktifitas perdagangan di kalangan masyarakat Arab saat itu adalah dengan mengirim barang-barang yang diangkut rombongan kafilah melintas padang pasir yang terik dan gersang. Perjalanan darat di Jazirah Arab saat itu, merupakan lalu lintas perdagangan yang cukup ramai, karena jalan laut saat itu dianggap tidak aman, maka kafilah-kafilah tersebut memilih jalan darat. ${ }^{38}$ Dalam kondisi yang penuh dengan bahaya dan memerlukan kekuatan dan ketahanan fisik, maka hal itu tidak memungkinkan bagi wanita untuk aktif berniaga. Sekarang telah terjadi perubahan yang cukup berarti dalam kehidupan kaum wanita pada umumnya. Wanita saat ini telah banyak berpengalaman dalam berbagai macam bidang kehidupan, karena mereka telah diberi kesempatan yang sama dengan laki-laki untuk mengembangkan pribadinya. Dengan adanya perubahan kondisi wanita yang disebabkan adanya perubahan kondisi sosial yang ada, maka kemampuan wanita untuk bertindak sebagai saksi dapat disejajarkan dengan pria.

36 Surat al-Baqarah (2) ayat 282

37 Rasyid Rida, Tafsir al-Manar, (Bairut: Dar al-Ma'rifah, ttp, juz iii), h. 124-125

38 Ahmad Amin, Fajr al-lslam, (Singapore: Maktabah Sulaiman MarT, 1965), h. 12. 


\section{b. Saksi dalam Perzinaan}

Allah SWT berfirman:

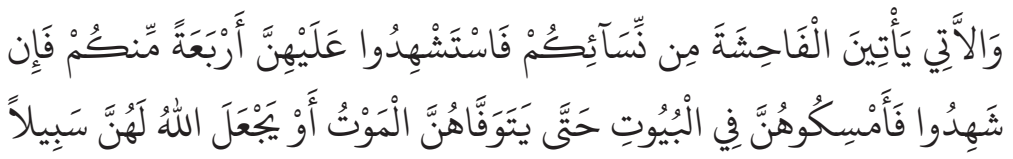

"Dan (terhadap) para wanita yang mengerjakan perbuatan keji (zina) hendaklah ada empat orang saksi diantara kamu (yang menyaksikannya). Kemudian apabila mereka telah memberi kesaksian, maka kuranglah mereka itu dalam rumah sampai mereka menemui ajalnya atau sampai Allah memberi jalan yang lain kepada mereka". ${ }^{39}$

Dari ayat tersebut, para ulama mensyaratkan bahwa terhadap tuduhan perzinaan harus dikemukakan empat orang saksi. ${ }^{40}$ Berkaitan dengan empat orang saksi dalam kasus perzinaan, Syaltut mengemukakan pendapatnya sebagai berikut: Seseorang boleh mengalirkan darah karena mempertahankan kehormatan rumah tangganya (kasus zina) walaupun tanpa empat orang saksi, hal itu semata mata sebagai pembelaan kehormatannya, manakala bukti telah kuat. ${ }^{41}$

Dari pendapat yang dikemukakannya tersebut dapat dinyatakan bahwa jika secara material bukti-bukti telah kuat mengenai terjadinya perzinaan antara seorang laki-laki dengan wanita bukan isterinya yang melanggar kehormatan orang lain, maka hakim bisa memutuskan perkara tanpa empat orang saksi.

Dengan demikian, pemikiran Syaltut tersebut mengandung mashlahah, karena, jika saja kasus melanggar kehormatan orang lain (zina) harus dengan empat orang saksi dalam pembuktiannya, sedangkan hal itu sulit dipenuhi, sedangkan bukti-bukti lain telah menguatkan, maka akan tidak terlindungi kehormatan rumah tangga seseorang, dan akan tergoyahkan

39 QS. Al-Nisa(3):15-16

40 Abd al-Rahman al-Jaziri, al-Fiqh Ala al-Mazahib al-arba'ah, (Bairut: Dar al-Fikri), 1985

41 Mahmud Syaltut, al-lslam Aqidah wa al-Syari'ah, (Kairo: Dar al-Syuruq, 1980), h. 345 
pula ketenangan rumah tangganya. Padahal ketenangan rumah tangga merupakan fondasi penting untuk menciptakan keharmonisan suatu perkawinan dan kelestariannya.

Berdasarkan mashlahah ini pula, Umar bin Khattab pernah mendera peminum khamer delapan puluh kali. Sedangkan pada zaman $^{42}$ Nabi peminum khamer hanya didera empat puluh kali. Umar ibn Khattab, seorang sahabat Nabi yang dianggap oleh jumhur ulama sebagai imam ahli ra'y, banyak sekali ia berijtihad dan berfatwa dengan menggunakan pertimbangan mashlahah seperti; tidak memberikan hak muallaf dari harta zakat, membunuh orang banyak karena bersama-sama membunuh seseorang, mendera peminum khamer delapan puluh kali, tidak melaksanakan hukuman potong tangan atas pencuri pada musim paceklik dan dalam suasana perang, mengharamkan laki-laki muslim menikah dengan wanita kitabiyah, memerintahkan seseorang mengalirkan air di tanah orang lain meskipun dilarang oleh pemiliknya, mengadakan penjara, mengatur adminstrasi pemerintahan, memungut pajak dari rakyat yang mampu untuk mencukupi biaya pemerintahan, tidak membagi tanah rampasan perang dan tetap membiarkannya ditangan pemiliknya, masalah talak tiga, dan masih banyak lagi. ${ }^{43}$

Kalau dilihat dari segi metodologi hukum Islam, maka dapat dikatakan, bahwa cara pengambilan kesimpulan Syaltut dalam mengistinbatkan hukum mengenai persoalan di atas adalah menggunakan maslahah. Ia merumuskan semacam kaidah sebagai berikut: Dan jika suatu masalah itu didapatkan, maka disitulah syariat Allah.

\section{c. Bunga Tabungan}

Mahmud Syaltut, seorang cendikiawan dari Mesir berpendapat bahwa sesungguhnya prinsip syariat Islam dalam bidang muamalah adalah terpenuhinya maşlahah,

42 M. Atho Mudzhar, Membaca Gelombang Ijtihad antara tradisi dan Liberasi, (Yogyakarta: Titian Ilahi Press, 1998), h. 50-51

43 Ibid., h. 39-67

HIKMAH, XIV, No. 1, 2018 95 
terlindunginya aturan dan hak-hak serta meningkatnya taraf hidup. ${ }^{44}$ Sebagai contoh ia menghalalkan bunga tabungan karena dipandang memberikan kemashlahatan dan tidak menimbulkan kemudharatan, baik yang menabung atau yang menerima tabungan, kedua-duanya mendatangkan kebaikan. Didalamnya tidak terdapat orang yang menganiaya dan teraniaya, dengan kata lain tidak ada unsur pemerasan atau pemaksaan. Laba yang diberikan oleh tabungan adalah sebagai suatu daya tarik saja.

Berdasarkan hal ini, Syaltut membolehkan bunga tabungan itu berdasarkan ayat 220 dan 279 surat al-Baqarah. Dalam hal ini, Muhammad Abduh berpendapat, bahwa haram ataupun halalnya bunga tadi bertitik tolak pada: Allah tidak mengharamkan sesuatu kecuali karena mendatangkan mudharat pada dirinya, dan tidak menghalalkan sesuatu, kecuali karena bermanfaat pada dirinya. ${ }^{45}$

Pendapat Syaltut tersebut berbeda dengan kalangan ulama Mesir saat itu yang menyatakan bahwa, keuntungan yang diberikan oleh Bank adalah haram. ${ }^{46}$

Dalam argumen yang dikemukakan, ia menyatakan bahwa uang yang dititipkan di Bank itu pada dasarnya merupakan penyertaan modal pemilik uang untuk kelancaran pengelolaan bank. Pendapat Syaltut ini dapat dijabarkan, bahwa terhimpunnya sejumlah modal daripada penabung itu dapat dimanfaatkan untuk suatu usaha. Dengan demikian dapat dikatakan, bahwa Bank dapat diqiyaskan dengan aktivitas syirkah, dalam menghimpun modal usaha. Lebih tepat lagi sebagai syirkah al-mud̄ārabah, yaitu penabung uang sebagai şāhib al-māl dan pihak Bank sebagai muḍārib (yang menjalankan usaha) yaitu bertindak sebagai pemegang kepercayaan dari pemilik modal.

\footnotetext{
44 Mahmud Syaltut, al-lslam Aqidah wa al-Syariah,h.391

45 Muhammad abduh, Tafsir al-Manar, (Cairo: Maktabah al-Qahiroh, juz III, cet IV, 1324), hal.

46 Mahmud Syaltut, al-Fatawa, h. 351
} 97 


\section{E. KESIMPULAN}

1. Istilah ahli ra'y digunakan untuk menyebut kelompok pemikir hukum Islam yang memberi porsi akal lebih banyak dibanding pemikir lainnya. Sebenarnya ahli ra'y bukanlah berarti kelompok yang meninggalkan hadits. Mereka juga menggunakan hadits sebagai dasar penetapan hukum Islam. Hanya, mereka dalam melihat kasus penetapan hukum berpendapat bahwa nash syar'i itu mempunyai tujuan tertentu, dan nash syar'i secara kumulatif bertujuan mendatangkan mashlahat manusia.

2. Dalam mengistinbatkan hukum Islam ahli ra'y merujuk kepada al-Qur'an, Sunnah, dan Ijma. Apabila tidak ditemui maka mereka menyegerakan untuk memutuskan suatu perkara dengan ra'y. Baik ahli ra'y maupun ahli hadits sebenarnya samasama menggunakan ra'y dalam istinbat hukum Islam, akan tetapi letak perbedaan hanya sebatas metode penggunaannya saja. Faktor lingkungan sangat mempengaruhi perkembangan arah tujuan kedua mazhab tersebut dalam menentukan jawaban daripada permasalahan-permasalahan yang terjadi disekitarnya walaupun masih banyak faktor yang lainnya.

3. Dampak pemikiran hukum Islam ahli ra'y dan relevansinya terhadap bebarapa pemikiran hukum Islam kontemporer dapat dilihat dalam contoh bolehnya kesaksian wanita, apalagi jika kaum wanita itu berada dalam tradisi ikut terlibat dalam urusan perdagangan, keuangan dan hutang piutang, maka mereka tentu saja berhak mensejajarkan diri menetapkan kepercayaan kesaksian seorang wanita, sebagaimana kepercayaan kesaksian seorang laki-laki. Begitu juga dalam masalah saksi dalam perzinaan, jika secara material buktibukti telah kuat mengenai terjadinya perzinaan antara seorang laki-laki dengan wanita bukan isterinya yang melanggar kehormatan orang lain, maka hakim bisa memutuskan perkara tanpa empat orang saksi. Begitu juga dengan masalah bunga bank, bunga tabungan dapat memberikan kemashlahatan dan tidak menimbulkan kemudharatan, baik yang menabung atau yang menerima tabungan, kedua-duannya mendatangkan 
kebaikan. Didalamnya tidak terdapat orang yang menganiaya dan teraniaya, dengan kata lain tidak ada unsur pemerasan atau pemaksaan. Contoh di atas tentunya masih menyisakan perbedaan pendapat di kalangan para ulama, tapi penulis berusaha mengedepankan suatu pemikiran yang sesuai dengan pemikiran hukum Islam ahli ra'y.[] 